\title{
Role of serum protein in the ocular manifestations of vitamin A deficiency
}

\author{
I). G. BAISYA, * L. C. DUTTA, * P. GOSWAMI, $†$ AND S. K. SAHA
}

From the Departments of Ophthalmology* and Biochemistry†, Gauhati Medical College, Gauhati, $\frac{\mathrm{Q}}{\mathrm{D}}$ Assam, India

The ocular lesions of vitamin A deficiency, in order of severity, are brown pigmentation of the conjunctiva, defective dark adaptation (clinically manifested as night blindness), Bitot's spot, xerophthalmia, and keratomalacia. The first four conditions are due to the mild chronic form of vitamin A deficiency and the last to the severe acute form.

Night blindness, xerophthalmia, Bitot's spot, and keratomalacia were identified and treated with liver and liver oil before the discovery of the vitamins, but the pathogenesis $ᄋ$ of these ocular manifestations of vitamin A deficiency are not yet known.

Supplementary protein in the diet causes early and complete disappearance of Bitot's spot and xerophthalmia (Yourish, I953; Vaughan, I954; Reddy, I965; Gupta, Dhir, and $\frac{0}{0}$ Agarwal, 1968). This may be due to an interrelation of the metabolic functions of protein and vitamin $\mathrm{A}$, and the present study seeks to elucidate this relationship.

\section{Materials and methods}

Four groups of children aged I to 8 years, who were affected by keratomalacia, xerosis, Bitot's spot, and xerosis with Bitot's spot, were admitted to the Eye Ward of Gauhati Medical College Hospital. A complete nutritional and clinical examination, with estimation of serum vitamin A, total serum $\stackrel{\varnothing}{\Phi}$ protein, serum albumin, and serum globulin was carried out.

The children received the standard hospital diet supplemented with a single mega dose of vitamin A (roo,ooo I.U. - Arovit, Roche) as recommended by the Indian Council of Medical Research ( 1967 ) and $\mathrm{I} \cdot 5$ g. milk protein (Casilan) per kg. body weight daily for $\mathrm{I}_{5}$ days, after which the examination was repeated.

Children with no signs of malnutrition were used as a control group and were treated and examined in the same way.

Serum vitamin A was estimated by the method of Kaser and Stekol (1943), using a Klett-Semmer-ळi son photoelectric colorimeter. Total serum protein, serum albumin, and serum globulin were estimated by the method of $\mathrm{Wu}(1920,1922)$.

\section{Results}

CONTROLS (Table I, opposite). After treatment there was no significant increase in the $\widetilde{N}$ mean values. The mean total serum protein was raised from $7 \cdot 3 \mathrm{I}$ to $7.63 \mathrm{~g} / \mathrm{I}$ oo $\mathrm{ml}$. and $\tilde{O}$ the serum vitamin A rose by I I 8 per cent. The albumin/globulin ratio fell from $2 \cdot I_{2}$ to $2 \cdot 08$ (Table II, overleaf).

KERATOMALAGia (Table I) The mean serum vitamin A level increased two-fold after $\stackrel{\varrho}{\mathbb{C}}$ treatment. The total serum protein in this group varied from 4.26 to $7.60 \mathrm{~g}$. $/ \mathrm{Ioo} \mathrm{ml} . \stackrel{\mathcal{N}}{\rightarrow}$ (mean $5.82 \mathrm{~g} / .100 \mathrm{ml}$.). Along with the low serum protein level, the albumin/globulin 
Table I Total serum protein, serum albumin, serum globulin, and serum vitamin $A$ in eight normal healthy children, eleven with keratomalacia, six with xerosis, six with Bitot's spot, and six with xerosis and Bitot's spot before and after treatment.

\begin{tabular}{|c|c|c|c|c|c|c|c|c|c|c|c|}
\hline \multirow[t]{2}{*}{ Diagnosis } & \multirow{2}{*}{$\begin{array}{l}\text { Case } \\
\text { No. }\end{array}$} & \multirow{2}{*}{$\begin{array}{l}\text { Age } \\
(y r s)\end{array}$} & \multirow[t]{2}{*}{ Sex } & \multicolumn{2}{|c|}{$\begin{array}{l}\text { Total protein } \\
(\mathrm{g} . / \mathrm{I} 00 \mathrm{ml} .)\end{array}$} & \multicolumn{2}{|c|}{$\begin{array}{l}\text { Serum albumin } \\
(\mathrm{g} . / \mathrm{1} 00 \mathrm{ml} .)\end{array}$} & \multicolumn{2}{|c|}{$\begin{array}{l}\text { Serum globulin } \\
(\mathrm{g} . / 100 \mathrm{ml} .)\end{array}$} & \multicolumn{2}{|c|}{$\begin{array}{l}\text { Serum vitamin } A \\
(\mu g . / 100 \mathrm{ml} .)\end{array}$} \\
\hline & & & & Before & After & Before & After & Before & After & Before & After \\
\hline \multirow[t]{9}{*}{ Control } & I & $\mathbf{I}$ & $\mathbf{M}$ & $7 \cdot 80$ & $7 \cdot 80$ & $5 \cdot 44$ & $5 \cdot 98$ & I $\cdot 90$ & $1 \cdot 82$ & $5^{6}$ & 60 \\
\hline & 2 & 5 & M & $7 \cdot 56$ & $7 \cdot 55$ & $5 \cdot 94$ & $4 \cdot 44$ & $1 \cdot 62$ & $3 \cdot 21$ & $5^{2}$ & 64 \\
\hline & 3 & 3 & $\mathbf{M}$ & $5 \cdot 80$ & $7 \cdot 85$ & $3 \cdot 80$ & $6 \cdot 16$ & $2 \cdot 00$ & $1 \cdot 69$ & 60 & 66 \\
\hline & 4 & $3 \frac{1}{2}$ & $\mathbf{F}$ & $7 \cdot 50$ & $7 \cdot 80$ & $4 \cdot 50$ & $5 \cdot 62$ & $3 \cdot 00$ & $2 \cdot 18$ & $5^{\circ}$ & 66 \\
\hline & 5 & 8 & $\mathbf{M}$ & $7 \cdot 20$ & $7 \cdot 50$ & $4 \cdot 50$ & $4 \cdot 50$ & $2 \cdot 70$ & $3 \cdot 00$ & $5^{2}$ & $5^{8}$ \\
\hline & 6 & 6 & $F$ & $7 \cdot 65$ & $7 \cdot 65$ & $5 \cdot 25$ & 5.05 & $2 \cdot 40$ & $2 \cdot 60$ & 60 & 62 \\
\hline & 7 & 4 & $\mathbf{M}$ & $7 \cdot 75$ & $7 \cdot 67$ & $5 \cdot 20$ & $4 \cdot 65$ & $2 \cdot 55$ & $3 \cdot 02$ & $5^{8}$ & 60 \\
\hline & 8 & $2 \frac{1}{2}$ & $\mathbf{M}$ & $7 \cdot 25$ & $7 \cdot 25$ & $4 \cdot 85$ & $4 \cdot 85$ & $2 \cdot 40$ & $2 \cdot 40$ & $5^{0}$ & 54 \\
\hline & \multicolumn{3}{|c|}{ Mean } & $7 \cdot 31$ & $7 \cdot 63$ & $4 \cdot 93$ & $5 \cdot 16$ & $2 \cdot 32$ & $2 \cdot 49$ & $34 \cdot 75$ & $6 \mathrm{I} \cdot 25$ \\
\hline \multirow{12}{*}{$\begin{array}{l}\text { Kerato- } \\
\text { malacia }\end{array}$} & I & 4 & $\mathbf{M}$ & $7 \cdot 02$ & $7 \cdot 56$ & $3 \cdot 80$ & $5 \cdot 08$ & $3 \cdot 22$ & $2 \cdot 4^{8}$ & 24 & 60 \\
\hline & 2 & 8 & M & $6 \cdot 50$ & $8 \cdot 52$ & $4 \cdot 25$ & $4 \cdot 90$ & $2 \cdot 25$ & $3 \cdot 62$ & Io & 38 \\
\hline & 3 & 3 & $\mathbf{M}$ & $4 \cdot 70$ & $6 \cdot 78$ & $3 \cdot 00$ & $4 \cdot 64$ & $1 \cdot 71$ & $2 \cdot 14$ & 28 & $4^{8}$ \\
\hline & 4 & $2 \frac{1}{2}$ & $\mathbf{M}$ & $5 \cdot 96$ & $8 \cdot 8 o$ & $2 \cdot 95$ & $5 \cdot 04$ & $3 \cdot 01$ & $3 \cdot 76$ & 16 & $4^{2}$ \\
\hline & 5 & 6 & $\mathbf{M}$ & $5 \cdot 06$ & $7 \cdot 28$ & $3 \cdot 32$ & $4 \cdot 74$ & $1 \cdot 74$ & $2 \cdot 54$ & 23 & $5^{2}$ \\
\hline & 6 & 6 & $\mathbf{M}$ & $7 \cdot 40$ & $7 \cdot 52$ & $4 \cdot 52$ & $4 \cdot 74$ & $2 \cdot 88$ & $2 \cdot 78$ & 23 & 54 \\
\hline & 7 & 8 & $\mathbf{M}$ & $5 \cdot 64$ & $7 \cdot 28$ & $2 \cdot 00$ & $3 \cdot 4^{8}$ & $3 \cdot 64$ & $3 \cdot 80$ & 48 & 65 \\
\hline & 8 & 5 & $\mathbf{M}$ & $4 \cdot 62$ & $6 \cdot 35$ & $2 \cdot 00$ & $4 \cdot 4^{1}$ & $2 \cdot 26$ & I $\cdot 94$ & 20 & 44 \\
\hline & 9 & 6 & $\mathbf{F}$ & $6 \cdot 30$ & $7 \cdot 80$ & $2 \cdot 20$ & $4: 39$ & $4 \cdot 10$ & $3 \cdot 4^{1}$ & 23 & $5^{2}$ \\
\hline & Io & 8 & $\mathbf{M}$ & $7 \cdot 60$ & $7 \cdot 78$ & $4 \cdot 00$ & $4 \cdot 4^{8}$ & $3 \cdot 60$ & $3 \cdot 30$ & 40 & 65 \\
\hline & I I & 8 & $\mathbf{F}$ & $4 \cdot 71$ & $6 \cdot 78$ & $3 \cdot 60$ & $4 \cdot 64$ & $1 \cdot 71$ & $2 \cdot 14$ & 34 & 60 \\
\hline & \multicolumn{3}{|c|}{ Mean } & $5^{\cdot 82}$ & $2 \cdot 20$ & $3 \cdot 25$ & $4 \cdot 59$ & $2 \cdot 73$ & $2 \cdot 90$ & $26 \cdot 27$ & $5^{2 \cdot 72}$ \\
\hline \multirow[t]{7}{*}{ Xerosis } & $\mathbf{I}$ & 6 & $\mathbf{M}$ & $6 \cdot 35$ & $6 \cdot 77$ & $1 \cdot 87$ & $3 \cdot 24$ & $4 \cdot 4^{8}$ & 3.53 & 44 & $5^{0}$ \\
\hline & 2 & 5 & $\mathrm{~F}$ & $7 \cdot 01$ & $7 \cdot 20$ & $5 \cdot 32$ & $5 \cdot 98$ & I 69 & $1 \cdot 22$ & 34 & 49 \\
\hline & 3 & 6 & $\mathbf{F}$ & $5 \cdot 89$ & $6 \cdot 8 o$ & $3 \cdot 4^{8}$ & $4 \cdot 25$ & $2 \cdot 41$ & $2 \cdot 55$ & $5^{6}$ & 65 \\
\hline & 4 & 4 & $F$ & $6 \cdot 82$ & $6 \cdot 92$ & $5 \cdot 20$ & $5 \cdot 28$ & $1 \cdot 62$ & $1 \cdot 64$ & 52 & 60 \\
\hline & 5 & $I \frac{1}{2}$ & $\mathbf{M}$ & $6 \cdot 60$ & $7 \cdot 29$ & $2 \cdot 60$ & $5 \cdot 98$ & $4 \cdot 00$ & $2 \cdot 31$ & 46 & 50 \\
\hline & 6 & 3 & $\mathbf{F}$ & $6 \cdot 10$ & $6 \cdot 92$ & $3 \cdot 10$ & $5 \cdot 28$ & $3 \cdot 00$ & $\mathrm{I} \cdot 64$ & 40 & $4^{8}$ \\
\hline & \multicolumn{3}{|c|}{ Mean } & $6 \cdot 46$ & $6 \cdot 98$ & 3.59 & $5 \cdot 00$ & $2 \cdot 87$ & $2 \cdot 15$ & $45 \cdot 33$ & $53 \cdot 67$ \\
\hline \multirow[t]{7}{*}{ Bitot's spot } & I & $3 \frac{1}{2}$ & $\mathbf{M}$ & $4 \cdot 78$ & $7 \cdot 02$ & $3 \cdot 5^{8}$ & $5 \cdot 28$ & $1 \cdot 20$ & $\mathrm{I} \cdot 74$ & 20 & 52 \\
\hline & 2 & 5 & $\mathbf{F}$ & $5 \cdot 20$ & $7 \cdot 02$ & $3 \cdot 80$ & $5 \cdot 21$ & $1 \cdot 40$ & $I \cdot 8 I$ & 40 & $5^{6}$ \\
\hline & 3 & 4 & $\mathbf{F}$ & $5 \cdot 30$ & $6 \cdot 40$ & $2 \cdot 84$ & $4 \cdot 20$ & $2 \cdot 46$ & $2 \cdot 20$ & 24 & 44 \\
\hline & 4 & 4 & $M$ & $6 \cdot 40$ & $7 \cdot 02$ & $3 \cdot 10$ & $5 \cdot 21$ & $3 \cdot 30$ & $\mathbf{I} \cdot 8 \mathrm{I}$ & 40 & $5^{6}$ \\
\hline & 5 & 3 & $\mathbf{M}$ & $5 \cdot 70$ & $6 \cdot 80$ & $2 \cdot 90$ & $4 \cdot 25$ & $2 \cdot 80$ & $2 \cdot 55$ & 26 & 44 \\
\hline & 6 & I $\frac{1}{2}$ & $\mathbf{M}$ & $4 \cdot 72$ & $6 \cdot 90$ & $3 \cdot 20$ & $4 \cdot 5^{2}$ & $1 \cdot 5^{2}$ & $2 \cdot 3^{8}$ & 22 & 40 \\
\hline & \multicolumn{3}{|c|}{ Mean } & $3 \cdot 35$ & $6 \cdot 86$ & $3 \cdot 23$ & $4 \cdot 77$ & $2 \cdot 11$ & $2 \cdot 08$ & $28 \cdot 66$ & $49 \cdot 00$ \\
\hline \multirow{6}{*}{$\begin{array}{l}\text { Xerosis and } \\
\text { Bitot's spot }\end{array}$} & $\mathbf{I}$ & 6 & $\mathbf{M}$ & $6 \cdot 03$ & $7 \cdot 28$ & $4^{\cdot 02}$ & $4 \cdot 44$ & $2 \cdot 01$ & $2 \cdot 84$ & 30 & $5^{2}$ \\
\hline & 2 & 3 & $\mathbf{M}$ & $6 \cdot 40$ & $7 \cdot 4^{8}$ & $4 \cdot 28$ & $5 \cdot 5^{6}$ & $2 \cdot 12$ & I $\cdot 92$ & 40 & 50 \\
\hline & 3 & $2 \frac{1}{2}$ & $\mathbf{M}$ & $6 \cdot 56$ & $7 \cdot 56$ & $4 \cdot 45$ & $5 \cdot 4^{8}$ & $2 \cdot I_{1}$ & $2 \cdot 08$ & 34 & 54 \\
\hline & 4 & $5 \frac{1}{2}$ & $\mathbf{M}$ & $7 \cdot 28$ & $7 \cdot 92$ & $4 \cdot 44$ & $5 \cdot 25$ & $2 \cdot 84$ & $2 \cdot 67$ & 28 & $5^{8}$ \\
\hline & 5 & 8 & $\mathbf{M}$ & $6 \cdot 25$ & $7 \cdot 28$ & $4 \cdot 20$ & $4 \cdot 62$ & $2 \cdot 05$ & $2 \cdot 66$ & 40 & 57 \\
\hline & \multicolumn{3}{|c|}{ Mean } & $6 \cdot 50$ & $6 \cdot 90$ & $4 \cdot 28$ & 5.07 & $2 \cdot 23$ & $2 \cdot 43$ & $34 \cdot 40$ & $54 \cdot 20$ \\
\hline
\end{tabular}


ratio was greatly altered even in cases in which the total serum protein was within the normal range (Cases I, 2, I0). After treatment the mean serum protein level was raised to $7 \cdot 20$ g./ I oo $\mathrm{ml}$. and the albumin/globulin ratio improved from $\mathrm{I} \cdot 34$ to $\mathrm{I} \cdot 60$ (Table II).

Table II Albumin/globulin ratio in different groups of cases before and after treatment

\begin{tabular}{|c|c|c|c|}
\hline \multirow{2}{*}{ Group } & \multirow{2}{*}{ No. of cases } & \multicolumn{2}{|c|}{ Albumin/globulin ratio } \\
\hline & & Before & After \\
\hline Control & 8 & $2 \cdot 12$ & $2 \cdot 08$ \\
\hline Keratomalacia & I I & $\mathbf{I} \cdot 34$ & $1 \cdot 60$ \\
\hline Xerosis & 6 & $1 \cdot 25$ & $2 \cdot 57$ \\
\hline Bitot's spot & 6 & $\mathbf{I} \cdot 53$ & $2 \cdot 24$ \\
\hline Xerosis with Bitot's spot & 6 & $\mathbf{I} \cdot 92$ & $2 \cdot 09$ \\
\hline
\end{tabular}

xE Rosis (Table I) The mean serum vitamin A level rose from $45 \cdot 33$ to $53 \cdot 67 \mu \mathrm{g}$./ $\mathrm{rooml}$. There was no increase in the total serum protein level. The albumin/globulin ratio improved from $1 \cdot 25$ to $2 \cdot 57$ (Table II).

вітот's s рот (Table I) The mean serum vitamin A level rose from $28 \cdot 66$ to $49 \cdot 00$ $\mu \mathrm{g}$./ $\mathrm{I}$ oo $\mathrm{ml}$. and the mean serum protein level rose by $28 \cdot 2$ per cent.

The albumin/globulin ratio rose from $1 \cdot 53$ to $2 \cdot 24$ (Table II).

XEROSIS AND BIтOT'S SPOT (Table I) There was a significant increase in the serung vitamin A level and, although there was no significant change in the mean serum proteir. level, the albumin/globulin ratio increased from $1 \cdot 92$ to $2 \cdot 09$ (Table II).

\section{Discussion}

McLaren (1964) suggested that the eyes were affected if the serum vitamin A level fell below $20 \mu \mathrm{g} . / 100 \mathrm{ml}$, , but in the present series keratomalacia, xerosis, and Bitot's spot occurred in patients with levels as high as $56 \mu \mathrm{g}$./ $100 \mathrm{ml}$., suggesting that hypovitaminosis A is not the only aetiological factor in the ocular lesions which accompany malnutrition. Dhir, Gupta, and Agarwal (1968) demonstrated that the administration of vitamin A alone was incapable of curing the ocular lesions of hypovitaminosis $\mathrm{A}$.

Though hypovitaminosis A was not frequently found in the present series, hypoproteinaemia with altered albumin/globulin ratio was noted almost in every case. Similar observations of hypoproteinaemia in cases of keratomalacia and xerophthalmia were made by Yap-Kie-Tiong (1957) and Gopalan, Ventakachalan, and Bhavani (1960). In our cases the serum protein level increased and the albumin/globulin ratio became normal after treatment, with clinical improvement of the ocular lesions.

The importance of giving protein as well as vitamin $\mathrm{A}$ in the treatment of hypovitaminosis A has been studied by various workers (Yourish, 1953; Vaughan, 1954; Bagchi, Halder, and Chowdhury, I959; Reddy, I965; Gupta and others, 1968). Yap-Kie-Tiong (1956) observed that the serum protein levels were lower in patients with keratomalacia than in those with xerophthalmia, while the concentration of vitamin A was approximately the same. It has also been reported that xerosis, Bitot's spot, and keratomalacia may occur when the serum vitamin A level is normal but the serum protein level is low (Cecil and Loeb, I951; Sen, I954; Yap-Kie-Tiong, I956; Venkataswamy, 1967). 
Protein deficiency produces a fatty infiltration of the liver and impairment of the normal functions of the liver cells. As the liver is a vital organ for vitamin A metabolism, protein deficiency prevents the availability of vitamin A to the body. Factors which influence the absorption, biosynthesis, and storage of vitamin A all tend to lower the serum vitamin A level (Abboud, Osman, and Massoud, 1968). Protein deficiency causes the rapid exhaustion of stored vitamin $A$, the impairment of digestion and malabsorption, and the reduction of power to utilize the small amounts of vitamin A and provitamins (Moore, 1960) which are still available in the body. Our study has shown that where the total serum protein level is low, the serum vitamin A level is also low. It is clear that protein plays a vital role in the prevention of the ocular manifestations of vitamin A deficiency, and that in the treatment of such cases protein and vitamin A should be given together.

\section{Summary}

Children with various ocular lesions due to hypovitaminosis A were treated with one mega dose of vitamin A and I.5 g. milk protein per $\mathrm{kg}$. body weight daily for 15 days. In almost every case the clinical condition improved, and the serum vitamin $A$ and protein concentration and the albumin/globulin ratio became normal. Both protein and vitamin A should be used in the treatment of the ocular manifestations of vitamin A deficiency.

The authors are grateful to Dr. S. N. Sarma, Principal of the Gauhati Medical College, for facilities to carry out this investigation, and to the Director General of the Indian Council of Medical Research for a financial grant.

\section{References}

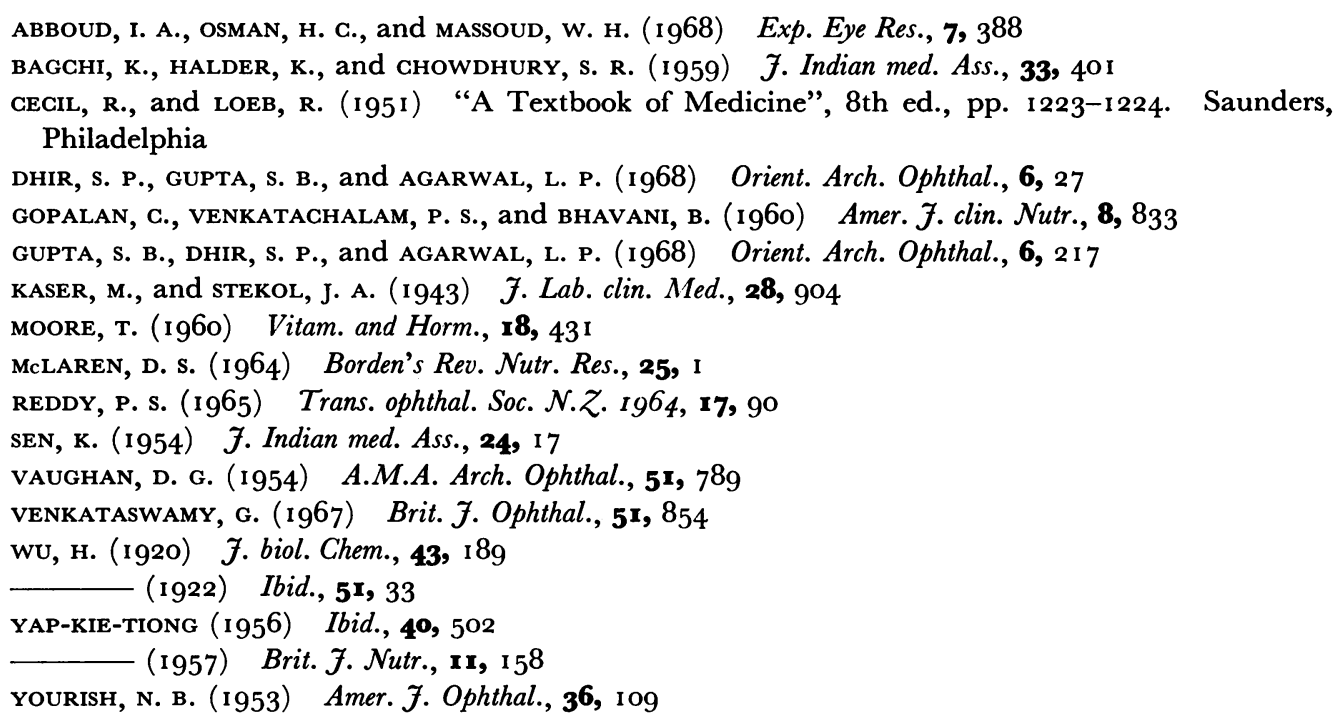

